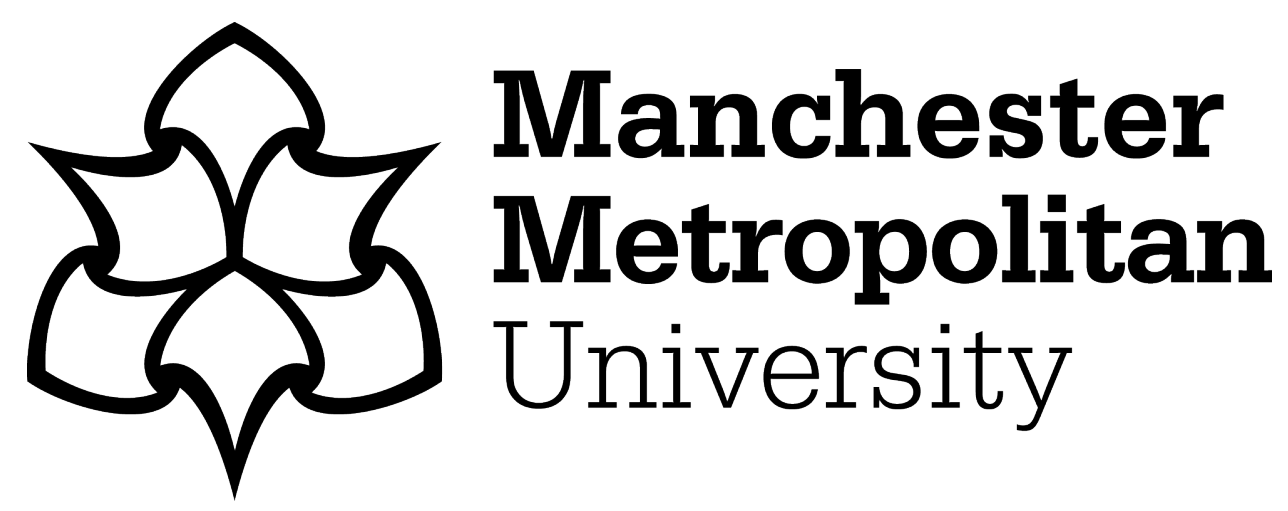

Wilkinson, David ORCID logoORCID: https://orcid.org/0000-0002-9036577X (2014) 'Prole Art Threat': The Fall, the Blue Orchids and the politics of the post-punk working-class autodidact. Punk \& Post Punk, 3 (1). pp. 67-82. ISSN 2044-1983

Downloaded from: https://e-space.mmu.ac.uk/623504/

Version: Accepted Version

Publisher: Intellect

DOI: https://doi.org/10.1386/punk.3.1.67_1

Please cite the published version 


\title{
'Prole Art Threat': The Fall, the Blue Orchids and the politics of the post-punk working-class autodidact
}

David Wilkinson, University of Manchester

\begin{abstract}
In much of the writing that exists on The Fall, a persistent myth is perpetuated of the inscrutable character of Mark E. Smith. One of the contributing factors to this myth concerns Smith's politics, commonly seen as ambiguous yet so far not analysed in detail. Here I shed some light on this issue. Furthermore, I wish to open up academic discussion on the work of The Blue Orchids, an outgrowth of The Fall, which developed an outlook inchoate in the original line-up, one which was lost when Smith became its driving force. There is a fascinating comparison to be made between the Fall and Blue Orchids on the basis of working-class negotiations of leftist post-punk at the dawn of Thatcherism. I examine how the two bands' cultural production and political attitudes towards freedom and pleasure were shaped by residual countercultural and class-based influences. I then consider the divergent outcomes of Smith's affinities with Thatcherism (which nevertheless retained oppositional elements) and The Blue Orchids' mystical rejection of both the New Right and New Pop in favour of an oppositional ethos of fulfilment that was part G. I. Gurdjieff and part Worker's Educational Association.
\end{abstract}

\section{Keywords}


post-punk

politics

Fall

Blue Orchids

working class

autodidact

left

Thatcherism

Reflection on the politics of The Fall faces a problem. In much of the writing that exists on the band, there is a persistent romantic myth of Mark E. Smith and The Fall as inscrutable. Both of the band's biographers have helped lay the groundwork (Ford 2003: xi; Middles and Smith 2003: 278), and music journalists too have long tended towards this position (Sinker 1988). In a perceptive article for The Quietus that analyses Smith's storysongs, for example, Taylor Parkes claims that 'The Fall's work... does not surrender readily to textual analysis' and concludes by regarding his own efforts as an exercise in futility (2010). Even the editors of the only academic collection on the band partly go along with the myth; despite a refreshing defence of the validity of intellectual analysis of The 
Fall, they also refer to the 'irreducibly enigmatic nature' of the band. Many of the subsequent articles in the collection base their analysis around a similar premise (Goddard and Halligan 2010: 5).

The myth of inscrutability concerns not just Smith's persona and the Fall's music, but also their politics. Mick Middles claims that 'the politics of The Fall... remain splendidly locked in ambiguity' (Middles and Smith 2003: 79), whilst the music promoter and associate of the band Alan Wise summarizes Smith's outlook as 'neither left nor right' (2005). Dick Witts touches on Smith's politics by positioning them midway between 'old Labour' and Thatcherism, but offers no sustained analysis (Goddard and Halligan 2010: 30).

I aim to shed some much-needed light on this question. The crux of my argument is that there is a fascinating comparison to be made between The Fall and the Blue Orchids (an outgrowth of the Fall) on the basis of working-class negotiations of leftist post-punk and New Pop during the early years of Thatcherism. ${ }^{i}$ As regionalist autodidacts, the bands were positioned awkwardly in relation to an often academically informed post-punk left and the reformist shift of New Pop. ${ }^{\text {ii }}$ I examine how the two bands' conflicting political stances were shaped by residual countercultural and class-based influences, focusing on their attitudes towards pleasure and freedom within the context of post-punk and the broader conjuncture. I also look at the relationship of these attitudes to their negotiation of the leftist post-punk label Rough Trade. 
My work is strongly informed by the cultural materialism of Raymond Williams. In line with its Marxist influences, the approach is avowedly historicist. One particularly useful element of Williams' historicism is its specificity. Cultural production must be related to more than the broader circumstances from which it emerges. It must also be considered in terms of what Williams called 'formations', or collective movements of cultural producers with shared characteristics, aims and values (1977: 119). This explains my focus on how the backgrounds, approaches and values of the two bands were bound up with leftist post-punk, the development of New Pop and the moment of Thatcherism. In the larger work from which this article is drawn, I make the case that a critical area of crossover between post-punk, the New Pop and Thatcherite neo-liberalism was a concern with the political definitions of pleasure and freedom.

Also central to my work is an understanding of culture as material production. Arguing against the model of economic base and cultural superstructure in some versions of Marxist theory, Williams claimed that the economic was 'a dynamic and internally contradictory process' in which cultural production was intimately bound up. Ultimately Williams would reason that "it is not "the base" and "the superstructure" that need to be studied, but specific and indissoluble real processes' (1977: 82). I therefore consider not only The Fall and the Blue Orchids' views of pleasure and freedom, but also how these views connected with their experience of Rough Trade. Before I move on to these themes, however, it is necessary to reflect on the significance of The Fall and the Blue Orchids' working-class background and autodidactic immersion in countercultural texts and values, since these shaped both their creative practice and political outlooks. 


\section{'Northern white crap that talks back'}

It is important to note of the habitus of both The Fall and the Blue Orchids that they did not share such influences as structuralist Marxism, early post-structuralism, academic feminism and conceptualist art theories acquired from art school and university, which shaped the practice of other leftist post-punk bands like Gang of Four, Scritti Politti and The Raincoats. Instead they drew from an eclectic range of literary, artistic, philosophical and musical sources which they discovered after having left secondary education. The founding members of The Fall felt alienated not only from the world of higher education prior to the intensification of university expansion, but also from the determinations of their working-class background (Ford 2003: 14-15). They thus reworked a residual, countercultural outlook long popular amongst working-class youth because of the autodidactic way in which it was usually acquired.

Simultaneously both bands retained some attachment to more conventional working-class traditions and identifications. This was partly in reaction against those within the same post-punk formation whose backgrounds, education and cultural production seemed to have little in common with the ways of life which were so central to The Fall and the Blue Orchids' experience. Their hostility towards this fraction of post-punk was understandable in the face of the patronizing treatment The Fall received early on from its representatives in the music press. One such example was Ian Penman, a member of art 
school band Scritti Politti's squat collective. Absorbed in the deconstructionist rhetoric of post-structuralism, Penman simply assumed that the band's rebellion was less sophisticated than his own, describing it as 'just the exchange of one set of limitations for another' (1978).

Although this process of socialization and the experience of post-punk did result in similarities of habitus, it would produce quite different political attitudes in Smith on the one hand and Martin Bramah and Una Baines on the other. Initially, however, it seemed the band was politically unified. Early Fall songs were informed by countercultural and libertarian left causes such as anti-fascism, anti-psychiatry, feminism and a critique of alienating capitalist industry. The band's first gig was put on by the Manchester Musicians Collective, a venture initiated by Dick Witts and Trevor Wishart, two classically trained musicians with 'New Left sympathies' (Heylin 2008: 313), which provided shared equipment, rehearsal and performance space to new bands. Smith showed interest early on in the issues of form, content and populism that pre-occupied many leftist post-punk bands: 'I don't agree with Tom Robinson playing anti-sexist songs against stale old Chuck Berry riffs...but I also don't agree with Henry Cow singing political tracts in front of quasi-classical avant-garde music, even though I enjoy it. It's very obscurist' (Lowenstein 1978).

Yet these concerns and values coexisted awkwardly with Smith's more reactionary leanings. When Bramah and Baines formed the Blue Orchids in 1979 after becoming a couple and leaving The Fall within a year of one another, Smith's political conflict was 
largely resolved. According to Smith, Bramah and Baines 'were never really part of The Fall. They were part of some other group. Blue Orchids was just about right. That's where their heads were at' (Middles and Smith 2003: 84). For this reason I concentrate on Fall songs that post-date the departure of Bramah and Baines in order to highlight the contrast in outlook between the bands.

Smith gradually developed an outlook with some affinities to Thatcherism, though never total support; although he claimed to have voted for a local Tory councillor (Snow 1984), Smith noted of Thatcher that 'people voted her in for their own greed' (Smith 1981). His conception of individual freedom, alloyed with libertine countercultural values, also tended to overreach the Thatcher government's, which was always caught between the amoral market and authoritarian social conservatism; when in 1986 the band released the amphetamine-hymning garage rock cover 'Mr Pharmacist' during a government crackdown on drugs, Smith claimed that 'if someone wants to smoke themselves to death or drink themselves to death... or whatever then it's their basic right' (Martin 1986).

As will become clear, however, Smith's interpretation of freedom and pleasure shared some degree of crossover with the New Right in its condemnation of the left on the basis of perceived authoritarianism and joylessness. This position was also coloured by class and educational differences: Smith characterized the libertarian left as a middle-class, over-educated malaise due to the significant proportion of former art school and univer- 
sity students, which made up the post-punk left. The aforementioned deployment of signifiers of his class background merged with libertine countercultural influences often served a specific political purpose which I go on to examine: it acted as a marker of the supposedly authentic as against those who were viewed as dogmatic, puritanical, naive and hypocritical. There are, however, salvageable elements of The Fall's cultural production from a left perspective. I concentrate here on Smith's desire for an alternative populism opposed to the reformist moment of New Pop and backed up by the belief that most people have the potential to enjoy more innovative and complex music than that which they are exposed to by a patronizing popular culture industry.

One of the most important things that the Blue Orchids represent in contrast to The Fall is that Smith's own former bandmates complicate his crude class stereotyping of the libertarian left. The Blue Orchids went on to develop the early politics of The Fall, adopting an outlook that focused on the politics of the personal whilst being simultaneously cooperative and democratic. The new band's approach was not informed by political theory like others on the post-punk left - Bramah has stated that 'I wasn't interested in left wing political concepts that you might learn when you're taking a degree' (Bramah 2011) though it was consciously politicized. The belief of both in working-class solidarity played a significant part (Ford 2003: 25-26), and Baines' early experience of the women's liberation movement in Manchester was also important, chiming with her rejection of a Catholic upbringing (Baines 2012). 
The unifying feature of the band's cultural production, however, was a residual countercultural interest in esotericism including the theories of the Russian mystics G. I. Gurdjieff and P. D. Ouspensky, Celtic legends, tarot and Robert Graves' The White Goddess ([1961] 1997), a treatise on poetry influenced by ancient mythology (Reynolds 2009: 210-14; Bramah 2011; Baines 2012). Curiously, the Blue Orchids often addressed the political themes usually made possible in post-punk by a more conceptualist stance, filtering them instead through a mystical concern with spiritual development bound up with the tradition of working-class self-improvement. As will become clear, this was a strategy with consequences both complementary and conflicting.

\section{'I don't know how to use freedom': The Fall, libertinism, class and the left}

A key feature of Smith's vision of freedom and pleasure coalesced first on the 1979 single 'Fiery Jack', sung from the imagined perspective of a hard-bitten, amphetaminefuelled 45-year-old pub alcoholic who Smith claimed 'is the sort of guy I can see myself as in twenty years' (McCullough 1980b). This was an identification which was to prove significant in terms of the character's values and vices. We are first introduced to Jack in the song through his self-description: 'My face is slack/and kidneys burn/in the small of my back/will never learn'. Whilst there is an acknowledgement of the negative effects of his lifestyle, the glee with which the lines 'I eat hot dogs/I live on pies' are delivered suggests that this kind of pleasure is only magnified by an awareness of its damaging side effects rather than troubled. Smith has recently reflected that 'Fiery Jack types' 'are quite 
heartening in a way... even though they're clearly doing themselves damage, there's a zest for life there... they're not all boring cunts' (Smith and Collings 2009: 89).

This is freedom and pleasure as libertinism, and, as Simon Reynolds and Joy Press have argued, is not without precedent in countercultural rock music, noting the frequent privileging of 'desire over responsibility, aesthetics over ethics' (1996: 147). Smith initiates in 'Fiery Jack' what would become a long-running association in The Fall's cultural production of libertinism with a supposedly authentic working-class world-view in opposition to all ethical and political frameworks, including Thatcherism: Jack is 'too fast to work', is opposed to 'free trade' and his speed habit and alcoholism might well have jarred with the petit bourgeois morality promoted by the government.

The fantasy that libertinism transcends politics, however, has always been just that. The libertine's claim on the freedom to pursue pleasures without concern for the potentially negative effects on self and others (or even because of the satisfaction gained from such effects) has much in common with the amoral market freedoms of Thatcherite neo-liberalism. It also disavows both social responsibility and egalitarianism. Thus it is inimical to the aims of the left, a fact made abundantly clear in a Fall interview soon after 'Fiery Jack's release. Smith claimed the song was about a variety of topics, including an 'antileft-wing' stance and 'ageism... people go round and think they're smart when they're 21 but these old guys you see have been doing it for years' (McCullough 1980b). It is not 
difficult to see where these two themes meet in the middle - there seems to be a silent rehearsal of the cliché that becoming more reactionary with age is a natural and desirable side-effect of maturity.

This was also evident in the musical form of 'Fiery Jack', with the song's rockabilly inflections immediately confirming its message regarding 'ageism'. The choice of musical elements is highly deliberate due to the genre being one which would likely have been to the taste of a middle aged working-class Mancunian in 1979, given the popularity of skiffle in the city's working men's clubs in the late 1950s. Smith coined the generic description 'Country 'n' Northern' in the same year 'Fiery Jack' was released, claiming that 'we are a very retrogressive band in a lot of ways' (Reynolds 2005: 195). He thus united formal traditionalism with political reaction, following the same logic but reacting in opposition to the equation made by post-punk groups like Scritti Politti between formal innovation and leftist politics. ${ }^{\text {iii }}$ Perhaps the most obvious indicator of the song's politics, however, is lyrical: Jack boasts 'I put down left-wing tirades'.

It is significant too that the phrase which follows is 'and the musical trades'. This implies that those Smith had in mind when he claimed 'people... think they're smart when they're 21' may well have included post-contemporaries such as Gang of Four whose work interrogated the political implications of certain pleasures and freedoms rather than celebrating their pursuit at all costs. Here the further significance of age becomes apparent along class and educational lines; the working-class life experience of 'Fiery Jack' is 
implicitly opposed to the presumed middle class background of the young arts graduates who often featured in the line-ups of leftist post-punk bands. Smith would go on to characterize these bands' questioning stances as destructive of freedom and pleasure per se in later Fall songs such as 'Slates, Slags, Etc.', though similar issues would also become apparent during the band's period on Rough Trade.

\section{'Just fuckin' sell the record you fuckin' hippy': The Fall and the music industry}

After signing initially to Miles Copeland's independent label Step Forward, The Fall moved to Rough Trade early in 1980. Sounds journalist and Fall champion Dave McCullough's vision of a 'dream come true, like two sources of the same river joining' (McCullough 1980a) proved overly optimistic, given that intervention of any kind on Rough Trade's part in the Fall's cultural production came to be viewed by Smith as unacceptably authoritarian, hypocritical and inappropriate in accord with his broader diagnosis of the libertarian left:

They'd go, er, the tea boy doesn't like the fact that you've slagged off Wah! Heat on this number. And fuckin'... the girl who cooks the fuckin' rice in the canteen doesn't like the fact that you've used the word 'slags'... Y'know, it is not the policy of Rough Trade to be supporting...' and I'd go, what the fuck 
has it got to do with you? Just fuckin' sell the record you fuckin' hippy.

(Cavanagh 1992)

The label's ethos of attempting to overcome the romantic division between artistic freedom and the mechanical functionality of business, instead working cooperatively and democratically (Hesmondhalgh 1997), was inexplicable anathema to Smith. It could be understood only as 'interfering' or in a manner which elided massively differing conceptions and practices of socialism with one another into one parody of authoritarianism: 'It was like living in Russia' (Smith and Collings 2009: 91). His conservative attitude towards the role of a record company could be seen in the fact that in order to play up his objections to critical feedback, he highlighted the supposed comments of employees whose roles would traditionally be seen as inferior and irrelevant to the music released.

But it was the combination of Smith's accusation that the label had failed to successfully promote and distribute The Fall's records (Pouncey 1984) and the description of Rough Trade as 'hippies', which cemented what kind of a dynamic was operating here. Smith's memoir compares Rough Trade's staff to children 'who'd returned home from school, yapping about this new thing - indie music - and their mam had given them a few quid to go and immerse themselves in it - to shut them up' (Smith and Collings 2009: 90). What is being espoused is not only a view of the label as hypocritically censorious, but a reactionary tabloid newspaper version of the countercultural left as over-privileged both 
in terms of class and education, youthfully naive and workshy, which Smith opposes once more to his vision of authentic working-class libertinism.

It is notable, then, that The Fall's 1982 album Hex Enduction Hour, released on the small independent Kamera during a hiatus from Rough Trade, features many of the most openly reactionary of Smith's lyrics (including the notorious 'where are the obligatory niggers?' from 'The Classical') and does not relent throughout, as though revelling in a newfound absence of perceived constraint. 'Deer Park' deals specifically with Rough Trade and its milieu, its musical accompaniment more than adequately expressing Smith's feelings towards the label. A furious backdrop of pummelling bassline, double drumkit beat and whining three-note synth pattern re-signifies the repetitive motifs of 1970s German progressive bands favoured by Smith, such as Neu! and Faust, conveying endless frustration in place of cosmic flow. Smith recounts 'I took a walk down West 11', referring to the postcode of Notting Hill where Rough Trade's shop and offices were located. The lines 'spare a thought for the sleeping promo department/they haven't had an idea in two years' bring to mind Smith's claims that the label had failed to promote The Fall. The comparison of the area to a deer park, meanwhile, and the lines 'yes dear chap, it hasn't changed that much/it's still a subculture art-dealer jerk-off' encapsulate Smith's rooting of the opposition between his own cultural politics and those he associated with Rough Trade in class terms, presenting the latter not just as those of a minority middle class fraction but comically exaggerating them as aristocratic. 
Whilst this class division was parodic and could not account for the numerous workingclass employees of Rough Trade and members of bands associated with it who shared its outlook, a further concern of Smith's regarding class and countercultural music formations did address a significant issue which was not initially dealt with by this fraction of the post-punk left. This was an issue not of production but of consumption, and was a problem that provided momentum for the rhetoric of New Pop - the fact that despite Rough Trade's initial aim of directly challenging major labels through sales, much of its output until the arrival of The Smiths did not sell in comparable quantities to that released by major labels.

For two different formations that had emerged from the initial moment of punk, this was a question of the appeal of post-punk cultural production, which relates directly to my concern with pleasure. Those associated with the 'real punk' of Oi! considered post-punk too obscure in its forms and concerns to have popular, including working class, appeal. But what they frequently viewed as populist was a noxious generalization of one fraction of working-class culture - the macho glorification of anti-intellectual hooliganism, which was conveyed through strained ranting and chanting accompanied by sped-up heavy metal power chords. This stance obscured the possibility that working-class people might be hostile to such attitudes and behaviour and be capable of enjoying more nuanced cultural production. 
Smith had reassuringly little time for this tendency, once expressing ironic concern for its main demagogue: 'Gary Bushell must have a really hard time interviewing all these bands who have nothing to say' (Penman 1980). He challenged Oi!'s claims to be broadly representative of working-class taste and concerns whilst simultaneously distancing The Fall from those bands he considered would only appeal to a minority middle-class fraction, claiming 'it was about time a fairly intelligent roots working-class band did something as opposed to art school types' (Smith 1980b) and

there were no groups around that I thought represented people like me or my mates. If I wanted to be anything, it was a voice for those people... The Fall had to appeal to someone who was into cheap soul as much as someone who liked [the] avant-garde. I even wanted the Gary Glitter fans. (Verrico 1998)

Those drawn to New Pop were far more sophisticated and successful than Oi! in their attempts to reach a broad audience, but as in the case of Scritti Politti, their logic often involved a capitulation to existing conventions of popular musical production with reformist political parallels that were more than merely metaphorical (Wilkinson 2014). Of this tendency, Smith reflected that

"when I started out I wanted to wipe out pop music and start again and I thought there were some writers who felt the same way. Now... being a pop musician is 
supposed to be something terribly clever and smart. Grown men and women write this crap. Well I'm still on the other side of the fence. (Lake 1984)

This did not mean a desire to remain marginal however - since the early days of The Fall, Smith has consistently stated his aim of reaching a wide audience without compromising on form and content, encapsulated in the pithily amusing claim that the band made 'music for the people that don't want it' (Wood 1978).

Smith's wry aphorism highlights the key distinction between his own populism and that of New Pop - a willingness to challenge and transform popular taste rather than adapt to market constructions of it. This could also be seen in the decision to do a tour of working men's clubs in unglamourous locations such as Doncaster and Preston in 1980, captured on the live album Totale's Turns. The recording is not without audience friction. Furthermore, Smith's concern over the amount of promotion done by Rough Trade also begins to look less reactionary considered from the angle of New Pop. Instead it looks more like the hope that significant sales can be achieved without the New Pop strategy of signing to a major label, thus fitting in with Rough Trade's initial ambitions to be an oppositional challenge to major labels rather than falling into the role of minority alternative.

The approach, unfortunately, was not hugely successful to begin with. A contributor to the influential Mancunian post-punk fanzine City Fun noted 'the same old crowd' at a 
Fall gig in 1983, arguing that 'Smith didn't [sell out]. So what? [The Fall's] faith in their ability to educate their audience was misplaced' (Anon._1982). Later in the 1980s, however, the band experienced a period of increased media coverage and higher sales despite holding fast to the refusal of artistic compromise and remaining signed to an independent label: their 1988 album I Am Kurious Oranj, for example, was written as a soundtrack to Michael Clark's avant-garde ballet themed around the 300th anniversary of William of Orange's accession to the British throne.

\section{'Politics is life': The Blue Orchids and an alternative definition of personal fulfil- ment}

In Blue Orchids songs such as 'Bad Education' and 'Work' there is an oppositional ethos of personal fulfilment and development which is simultaneously libertarian in its focus on the self and collectivist in its suggestions of how this fulfilment is to be achieved. Influenced by an inchoate awareness of the alienation produced by capitalism, Bramah and Baines shared a focus on the notion of pleasurable self-determination in a manner that was at odds both with Smith's libertinism and with the possessive individualism that characterized Thatcherism. As with the majority of politicized themes in their work, mysticism was a touchstone, with Bramah reflecting on Gurdjieff: 'I dwell on his ideas quite a lot, but they're not seen as revolutionary ideas. They are to me, but the revolution is "examine yourself"' (Bramah 2011). Gurdjieff described most people as 'machines' and specified the achievement of self-awareness as that which would alter this situation 
(Ouspensky 1949: 21). Self-awareness 'brings man to the realisation of the necessity for self-change' (Ouspensky 1949: 145). Gurdjieff, however, was no egalitarian on this issue, claiming that 'knowledge cannot belong to all, cannot even belong to many' (Ouspensky 1949: 37). Nor was he prescriptive on what the aim of fulfilment should be (152). This stood at odds with the Blue Orchids' view of the matter, which hoped for the self-realization of the many and united ethics with pleasure and politics: Baines once claimed in a Melody Maker interview that 'the biggest tragedy that exists is that people don't develop their potential' (Sutherland 1982a), and Bramah has said 'if you have a revolution on the streets it means nothing if you're not able to be a better person yourself' (Bramah 2011).

What, then, was being 'a better person' for the Blue Orchids? A substantial residual contribution to Bramah and Baines' attitude was the long British working-class tradition of educational 'mutual improvement' documented by Jonathan Rose and convincingly viewed as 'but one branch of a vast popular movement of voluntary collectivism' including economic initiatives such as friendly societies (Rose 2001: 59). Embodied in these networks was a powerful faith in the value of education rooted in its lack of official provision for the majority of people. For many on the left this extended not just to recognition of the benefits of education in the present but also to a belief in it as the principle of personal fulfilment in a future socialist society, beyond the equal distribution of material social wealth (Rose 2001: 53). Combining grassroots cooperation and an autodidactic stress on individual interpretation, mutual improvement allowed for the potential of what Terry Eagleton has specified as a socialist 'ethics of flourishing... in which each attains 
his or her freedom and autonomy in and through the self-realisation of others' (Eagleton 2003: 170). Accordingly, those who belonged to this tradition were often suspicious of the gradual state expansion of education in spite of its democratizing effect due to its simultaneous tendencies towards indoctrination, paternalism and the inculcation of a passive mode of learning (Rose 2001: 57).

Many decades later, there are close parallels with Bramah's distrust of official institutions, including his school education:

Being a kid I didn't fit into the education system so I was kind of against it on principle - I never took things as given or just because I was told it was so. I always gravitated towards things that interested me and pursued them. Very often it didn't fit in with what I was taught. (Bramah 2011)

In line with the collectivism of mutual improvement, this was not a solitary pursuit Bramah also notes that 'I was attracted to people [such as Baines and Smith] who did the same thing' (2011). Nor was it self-aggrandizing - Baines describes the song 'Low Profile' as 'about working without display... while you're doing positive things to make changes... when it's about the ego, flaunting what you're doing and showing off... then 
you're highlighting yourself and saying "look at me"' (Baines 2012), therefore counteracting the attempt to live less selfishly as a contribution towards greater egalitarianism.

In 'Bad Education', Bramah uses the institutions of education and the media as a metaphor for the negative, pacifying effects of hegemonic values on individual perception, describing the 'sticky situation' of having 'read too many books, seen too much TV' in a world-weary spoken-word refrain. The song avoids a collapse into individualism by directly addressing the listener from the beginning in a meekly charming idiom: 'I'm sorry to bother you but I'm afraid I want your attention/you see I've come to realise something that I think I should mention' and generalizing its observations: 'I'm not alone in this mess'. Another noteworthy formal device is the compression of lines with many syllables into the verse melody - Baines noted that '[Gurdjieff deliberately] writes in very long winded sentences so you have to really concentrate... the whole thing is getting people to wake up and use their mind' (2012).

The song's conveyance of the passivity inculcated by dominant values and the failure to 'wake up' through its lulling melody does however tend towards the mystic fatalism evident elsewhere in the band's cultural production; in 'Hanging Man', for example, Bramah sings 'everybody looks to me/I'm always looking to another star' and 'I do what I can but no-one changed their mind'. In 'Bad Education', this fatalism is lyrically present in the claim that 'this state is so established/there's no-one left to blame' and the sole glimmer of 
an alternative to a 'Bad Education' being the desire for monistic ego death in the line 'let's touch the flesh of the breeze and feel release', rather than for a different style of learning.

The Blue Orchids' second single 'Work' offers a more overt and positive solution, the resonances of its title fusing the dual influences on the band's politics of working-class autodidact culture and mysticism; Gurdjieff referred to the process of developing self-awareness as 'the work'. Rather than focusing on what Gurdjieff termed 'sleep', Bramah stated of the song that 'it's about working on yourself before you can do anything else, attaining values and a conscience. Stripping down the illusions of life without being negative or flowery' (Hanna 1981). The barked chorus of the song, consisting of the repetition of the word 'work', supports the intention of avoiding the 'floweriness' suggested by the passivity of 'Bad Education', as does the disorienting organ melody and the brittle timbre of the drum machine accompaniment. A purely negative effect, however, is avoided in lines such as 'we'll be the gold salmon swimming against the tide' - there is a sense of pleasure as well as difficulty in the imagery and the tone in which the line is sung. The use of 'we' is consistent throughout in a song that concerns personal development, complementing the direct address of the listener in 'Bad Education' and further underlining the band's understanding of freedom and pleasure as collective, cooperative affairs.

\section{'Working without display': Blue Orchids and the music industry}


When asked if the Blue Orchids' ethos was more in tune with Rough Trade than Smith, Baines agreed. She also compared the economic models used to run initiatives by the women's movement in Manchester to the cooperative manner in which Rough Trade operated, making a clear link between her cultural production and political activism (Baines 2012).

Bramah, too, said 'we thought things like Rough Trade would be collectives, would be communal...getting things done without the businessmen...not looking to make profit but just looking to make music and happenings and events'. This affinity, however, is difficult to assess from close analysis of the band's cultural production due to Bramah's anticonceptualist suspicion of singing about their 'business affairs' (Bramah 2011).

A more productive way of analysing The Blue Orchids' relationship with Rough Trade is to consider an ambiguity in the band's outlook rather than a harmony, one with parallels to the difficulties faced by Rough Trade. On the one hand, their stance was positive from the angle of pleasure. In line with Bramah and Baines' belief that personal fulfilment should not be a question of material acquisition, they viewed the opportunity of music being the main focus of their activity as profoundly important; cultural production valued for its own sake rather than in profit-driven, instrumentalist terms. Baines claimed that 'we were just doing it for the sake of it', while Bramah said that he values his current arrangement of day job combined with his new band Factory Star: 'I can make money and make music but I don't have to stop making music if it's not making me any money. Some bands, it's all about a career, and if the career stops, the music stops, which is sad' 
(Bramah 2011; Baines 2012). Baines told Simon Reynolds that 'we were pretty skint in those days, but we had a very interesting life. It's like, what do you call "rich"?' (Reynolds 2008). Expanding on this theme when I interviewed her, she asked 'don't you think people [who are concerned with status-driven consumption] - it's a bit sad? You know, like, "look at me with this big medallion" and you think "what a plonker"! Go and educate yourself, you know? Go and read some Oscar Wilde or something!' (2012), here, Baines unites the band's desire to make music for its own sake with the ethic of education discussed earlier.

On the other hand, there are two problems with framing the issue in this manner. The first concerns this definition of pleasure, in that both musicians and music press writers who had been involved with leftist post-punk were now beginning to characterize the Rough Trade milieu as joyless in contrast to the emergent formation of New Pop. Green Gartside of Scritti Politti described the DIY cassette band network supported by Rough Trade as 'irritating' (Reynolds 2005: 366), whilst Reynolds notes that Paul Morley's writing 'got frothy with exclamation marks [as if] trying to burst out into liberating frivolity'. Morley himself expresses pride in having upset the $N M E^{\prime}$ s leftist cartoonist Ray Lowry with he and Ian Penman's gossip column about London club-land, which hovered between irony and seriousness in its hymning of 'trousers that cost more than a month's unemployment benefit', plus their slogan 'dance, don't riot' (Reynolds 2005: 330). ${ }^{\text {iv }}$ In this context, the Blue Orchids' aversion not just to music subordinated to profit but their ascetic willingness to live on very little in exchange for a life devoted to music risked reinforcing this caricature of a puritanical scene - Baines claimed that they subsisted 
largely on porridge and lentils (Baines 2012). It also highlights a difficulty noted by Dave Hesmondhalgh in his sympathetic analysis of Rough Trade's long-term political effect on the British music industry. Hesmondhalgh argues that because the company only had limited resources in its early years, 'musicians were effectively trading in short-term financial security for a sense of collaboration and co-operation, and the feeling of a shared musical culture' (Hesmondhalgh 1997).

The other problem is directly related, and is one of freedom; it is the question of who benefits from the allowance of creative autonomy, free of record company assumptions of what will sell, and can be situated in the context of another of the New Pop ideologues' characterizations of post-punk. This was the accusation that it had become a self-indulgent ghetto, which had lost touch with the fact that it was part of a popular music market whose aim was to cater for a broad audience. Paul Morley asserted in his New Pop manifesto that 'no longer is there an acceptance of the cobwebbed corner... [New Pop groups] want a big display in the supermarkets' (Reynolds 2005: 364). In this context, the Blue Orchids' subtle political approach of 'working without display' may well have translated not as an admirable rejection of egotism but as an aloof desire to remain marginal, making them potential prime targets of New Pop critique.

It should be acknowledged however that, like Smith, the Blue Orchids attempted to formulate an alternative populism, which they justified in terms of spreading their ideas rather than material ambition. In an interview at the time of their debut album's release, 
Bramah said 'before you can tell anybody anything, they've got to be enjoying what you're saying or doing'. They implicitly distanced this stance from New Pop, with Baines adding 'we're not for people to escape to' (Sutherland 1982a). Baines' reflection on the contemporary music industry and populism also shows a clear awareness of a problem often sidelined by New Pop, which is that the market both creates and meets pleasures moulded by dominant values rather than abstractly catering to free individuals: 'Now look at it, Simon Cowell and all that nonsense, where they just take the soul out of everything and regurgitate this shit at people, and people want it. Their lives are being narrowed down' (Baines 2012).

The logic of New Pop, however, was not successfully circumvented in the long term. The Melody Maker music journalist Steve Sutherland, who had once championed the Blue Orchids, penned a deeply ambiguous review of the band's final EP littered with backhanded compliments: 'the Blue Orchids' appeal is viral, a sort of sapping sympathy for a sound so fragile it could just as easily expire as pull through' (Sutherland 1982b). Simon Reynolds has noted the prevalence of metaphors of health and sickness in the language of New Pop, employed in order to give the impression of post-punk as stagnant and decaying in contrast to the aspirations of New Pop (Reynolds 2005: 364). What goes unmentioned, however, is an undeniable between this rhetoric and Thatcher's repeated positing of her government's policies as 'medicine' in response to the media portrayal of Britain as 'the sick man of Europe' (Thatcher 1985). On this front, The Blue Orchids were once again vulnerable. In 1981, they had acted as tour band for Nico, formerly of 
the Velvet Underground, who had a chronic heroin addiction and was surrounded by others in a similar position. Bramah briefly experimented, whilst the band's long-term bassist and live guitarist became hooked and left to join Nico's backing band full-time (Reynolds 2009: 214).

This shift is reflected in some of the songs from the band's final EP that was released in late 1982. One such example is 'The Long Night Out'. The song uncharacteristically employs a synthesizer with a tone and melody faintly suggestive of fellow Mancunian postpunks Joy Division, whose singer Ian Curtis had committed suicide two years before. Its slow, listless pulse and piano accompaniment is even more comparable to the nihilistic trudge of 'The Eternal' from Joy Division's final album Closer, the lyrics of which dealt morbidly with a funeral. The lyrics of 'The Long Night Out', meanwhile, revelled masochistically in the addictive yet destructive properties of heroin - 'Another stupid kid trying to tame a plant/Just give me one hour with the juice of a flower' - and observed its stultifying effect: 'My heart is frozen/I have no will to do', lines which seemed a world away from the band's promotion of positivity and action in interviews and the counterparts of this attitude in other examples of their cultural production. The song, which is the last on the EP, features a bleak spoken finale - 'when everything around you stinks/where do you go?'. The question remains unanswered, a fact reflected in the musical conclusion of an unresolved chord progression which slowly fades out.

\section{'My vibrations will live on'}


Reflecting on the Fall years which this article has dealt with, Smith has claimed that 'I always used those right-wing comments to wind [the left-leaning music press] up because I knew how narrow-minded they were' (Middles and Smith 2003: 229). The defence - 'it was a joke all along' - is a cunning ideological move, rendering any objection to the views Smith has expressed on the left as confirmation of their apparent veracity. Whether serious or not, Smith wins either way. It is a conundrum that has bothered me numerous times when reading back my more critical analyses of Fall songs I otherwise enjoy. Have I simply taken Smith too seriously? Are my reservations, despite my own working-class background, an example of 'middle class revolt', as a Fall album title would have it? To accept this, though, would be to accept Smith's portrayal of those whose values I share as uniformly puritanical, lacking even the ability to appreciate ironic humour.

It would also leave the views expressed in the Fall's cultural production unchallenged on the assumption that they will always be taken with a pinch of salt rather than crystallizing or reinforcing such views in listeners. This is a difficult assumption to make, since at the time Smith was clearly mobilizing a particular structure of feeling shared by certain other participants in post-punk, such as Sounds journalist and Fall champion Dave McCullough. McCullough's hostility to the leftist and feminist art school bands The Raincoats and The Mekons was motivated by the same attribution of such views to naive 
middle class students: 'Self-righteous do-gooding...[a] conceited student mentality... irretrievably jinxed by [its] own middle-class, haplessly patronising attitudes' - and the same accusation of joylessness - 'The Raincoats is... an album void of love' (McCullough 1979). More recently, it is worth speculating whether potential listeners influenced by the pernicious ideological rhetoric of 'political correctness gone mad', in other words the neoliberal re-casting of progressive and leftist freedoms as authoritarian impositions, may well interpret aspects of Smith's outlook as complementary with their views. In the late 1970s and early 1980s the phrase had yet to gain the purchase it now holds, but it is telling that Smith claims that the band's work 'was totally un-PC for Rough Trade' in his 2008 memoir (Smith and Collings 2009: 90).

For all Smith's reactionary gestures, The Fall's post-punk period shows a complex, contradictory and sharply witty mind at work, broaching certain crucial issues that many on the post-punk left never quite managed to address convincingly or at all, such as the relationship of class, populism and countercultural music formations and institutions. Smith commented in a 1987 interview that 'when I was moving house I found a New Musical Express from $1981 \ldots$ those times were like the intellectual times of music, weren't they?... Philosophical bullshit... now it's like a complete reaction against that... in a way, I like it better like this' (Neal 1987: 95). The relief from post-punk's culture of scrutiny may have been seductive, but an awkward and conflict-ridden belonging to this formation of 'philosophical bullshit' often brought out the best in Smith and his band. It 
would be a shame for this to be buried under the vacuous and insulting stereotype of truculent, incomprehensible middle-aged northern working-class alcoholic, which now tends to frame Smith in the media.

Meanwhile, Simon Reynolds has argued that the legacy of the Blue Orchids was to have 'anticipated the "zen apathy", indolence-as-route-to-enlightenment, anti-stance of Happy Mondays' “Lazy-Itis"', and more broadly, the 'defeatism as dissidence' attitude of early 1990s 'slacker' alternative rock (Reynolds 2008). Although this view is clearly informed by an awareness of the political implications of the Blue Orchids' tendencies to fatalism and the drop-out connotations of their rejection of material acquisition, it presents the outlook of the band as far more pessimistic than it ever was in reality. As a summary, it neglects to consider that the Blue Orchids were one of the few leftist post-punk bands to build on and commit to a consistent, convincing oppositional ethos of pleasure and freedom, in addition to critiquing the dominant articulations of these themes.

Nor have they relinquished this ethos over the past thirty years. Bramah is still devoted to making music without the motive being profit or ego. Baines, meanwhile, has remained involved in political activism and community work with an emphasis on personal fulfilment, such as volunteering to make music with people suffering from mental health problems. She believes that 'we'll look back on the 60s, 70s, 80s [countercultural and leftist movements] as golden years' but expresses a guarded hope that the global communication enabled by the Internet has some transformative potential despite problems of 
censorship and ownership, and notes the existence of new cooperative, countercultural initiatives in Manchester (Baines 2012). We can only hope that such developments, informed by an oppositional tradition to which The Blue Orchids made an important if overlooked contribution, continue to flourish in our currently interesting times.

\section{Acknowledgements}

Thanks to Una Baines and Martin Bramah for generously giving their time up to be interviewed.

\section{References}

Anon. (1982),_untitled, City Fun,_-3:6,_June.

Baines, Una (2012), face to face interview_in Manchester, 3 July.

Blue Orchids (1981), 'Work', London: Rough Trade. (1982a), The Greatest Hit (Money Mountain), London: Rough Trade. 
(1982b), Agents of Change, London: Rough Trade.

Bramah, Martin (2011), face to face interview_in Manchester, 15 May.

Brazier, Chris (1977), 'United they Fall', Melody Maker, 31 December, p.9.

Cavanagh, David (1992), 'The Fall', Volume, no.4, September, available online at http://www.visi.com/fall/news/000620.html\#vol accessed 27 June 2014

Eagleton, Terry (2003), After Theory, London: Penguin.

The Fall (1980), 'Fiery Jack', London: Step Forward. (1982), Hex Enduction Hour, London: Kamera.

Ford, Simon (2003), Hip Priest: The Story of Mark E. Smith and the Fall, London: Quartet. 
Goddard, Michael and Halligan, Benjamin (2010), 'Introduction', in_Goddard and Halligan (eds.) Mark E. Smith and The Fall: Art, Music and Politics, Aldershot: Ashgate pp.119

Graves, Robert ([1961] 1997), The White Goddess: A Historical Grammar of Poetic Myth, Manchester: Carcanet.

Hall, Stuart and Jacques, Martin (1983) (eds), The Politics of Thatcherism, London: Lawrence and Wishart

Hanna, Lynn (1981), 'When reality rears its orchidacious head', NME, 20 June, p.6.

Hesmondhalgh, David (1997), 'Post-punk's attempt to democratise the music industry: The success and failure of rough trade', Popular Music, 3:16, pp. 255-74.

Heylin, Clinton (2008), Babylon's Burning: from Punk to Grunge, London: Penguin.

Lake, Steve (1984), 'After the Fall', Melody Maker, 21 April, pp.30-31. 
Lowenstein, Oliver (1978), 'A new career in a new town', Dangerous Logic, December, pp.2-4.

Martin, Gavin (1986), 'Revolting soul', NME, 30 August, pp.10-13.

McCullough, Dave (1979), 'Shrieks from the grove', Sounds, 8 December, p35. (1980a), 'Society's scourge', Sounds, 17 May, p35. (1980b), 'Totale turnaround', Sounds, 21 June, pp.18-19.

Middles, Mick and Smith, Mark E. (2003), The Fall, London: Omnibus.

Neal, Charles (1987), Tape Delay, Harrow: SAF.

Ouspensky, P. D. (1949), In Search of the Miraculous, New York: Harcourt, Brace and Company. 
Parkes, Taylor (2010), 'The Fall and Mark E. Smith as a narrative lyric writer', The Quietus,_19th March, http://thequietus.com/articles/03925-the-fall-and-mark-e-smith-as-a-narrative-lyric-writer. Accessed 10 March 2014.

Penman, Ian (1978), 'Between Innocence and Forbidden Knowledge Comes The Fall', NME, 19 August, pp.7-8

(1980), 'All Fall Down', NME, 5 January, pp.6-7.

Pouncey, Edwin (1984), 'Rough justice', Sounds, 9 June, p.24

Reynolds, Simon (2005), Rip It Up and Start Again: Postpunk 1978-1984, London: Faber and Faber.

(2008), 'Rip it up and start again: The footnotes',

http://ripitupfootnotes.blogspot.co.uk/. Accessed 10 March 2014.

(2009), Totally Wired; Post-Punk Interviews and Overviews, London: Faber and Faber. 
Reynolds, Simon and Press, Joy (1996), The Sex Revolts, Cambridge: Harvard University Press.

Rose, Jonathan (2001), The Intellectual Life of the British Working Classes, New Haven and London: Yale University Press.

Sinfield, Alan (2004), Literature, Politics and Culture in Postwar Britain, 3rd ed., London and New York: Continuum.

Sinker, Mark (1988), 'England: Look back in anguish', NME, 2 January, pp.14-16.

Smith, Mark E. (1980a), Dave Fanning's radio show, RTE, Ireland, 18 October. (1980b), 'Interviewed $V$ Sign fanzine issue 2', http://www.visi.com/fall/news/010930.html\#vsign. Accessed 10 Mar 2014. (1981), KPFA Radio, San Francisco, 10 July. 
Smith, Mark E. and Collings, Austin (2009), Renegade: The Lives and Tales of Mark E. Smith, London: Penguin.

Snow, Mat (1984), 'Before and after the Fall', $N M E, 3$ November, pp.6, 54

Sutherland, Steve (1982a), 'The sane old blues', Melody Maker, 1 May, p9. (1982b), 'On the sick list', Melody Maker, 27 November, p24.

Thatcher, Margaret (1985), 'Conservative Party Conference Speech', http://www.britishpoliticalspeech.org/speech-archive.htm?speech=131. Accessed 10 March 2014

Verrico, Lisa (1998), 'Are You Talking To Me?' Dazed and Confused, December, pp.5660.

Wilkinson, David (2014), 'Is 'Natural' in it?: Gang of Ffour, Scritti Politti and hegemony', in Rachel Carroll and Adam Hansen (eds), LitPop, Farnham: Ashgate (forthcoming). 
Williams, Raymond (1977), Marxism and Literature, Oxford: Oxford University Press.

Wise, Alan (2005), interview, The Wonderful and Frightening World of The Fall, London: BBC.

Witts, Richard (2010), 'Building up a band: Music for a second city', in Michael Goddard and Benjamin Halligan (eds), Mark E. Smith and The Fall: Art, Music and Politics, Farnham: Ashgate pp.19-33

Wood, Ian (1978), 'The Fall stumble into the void', Sounds, 8 April, p26.

\section{Contributor details}

David Wilkinson completed a Ph.D. on post-punk and politics at the University of Manchester (2013). He is currently Research Assistant on Matthew Worley and John Street's Leverhulme project 'Punk, Politics and British Youth Culture 1976-1984'. He has worked with Manchester Histories Festival and the Manchester District Music Archive, collaborating with Dave Haslam and MDMA founder Abigail Ward on the digital archiving of post-punk fanzine City Fun. He has also written music reviews for feminist website The F Word. 
Contact:

E-mail: d.b.wilkinson@reading.ac.uk

University of Reading

$\underline{\text { Whiteknights }}$

$\underline{\text { PO Box } 217}$

$\underline{\text { Reading }}$

$\underline{\text { Berkshire }}$

$\underline{\text { RG6 6AH }}$

United Kingdom

Notes 
'I use the term 'Thatcherism' in a manner informed by cultural theorist Stuart Hall (1983), who coined the term to identify and analyse the political project that succeeded the crisis of the post-war 'welfare-capitalist' consensus (Sinfield 2004: 17) in 1970s Britain. Thatcherism combined economic liberalism with social conservatism and was initiated by the Conservative government of Margaret Thatcher, elected in May 1979.

${ }^{\text {ii }}$ A 'subvert-from-within' strategy of abandoning post-punk independence and formal difficulty in a bid for the charts, which strongly influenced early 1980s British pop. It was promoted largely by London-based music journalists such as Paul Morley. Post-punk bands that followed this path include Scritti Politti and Heaven 17.

iii Smith's views on this matter remained contradictory, however, due to the simultaneous pursuit of idiosyncrasy that contributes towards the band's post-punk status, and his consistent hostility towards punk bands who continued to follow the generic template established in the movement's first two years. Even The Fall's rockabilly and 'Country 'n' Northern' songs like 'Fiery Jack', 'The Container Drivers' and 'Fit and Working Again' avoided pastiche, a fact implicit in the neologism Smith used to describe them.

${ }^{\text {iv }}$ Lowry was not, however, humourlessly puritanical, as the nature of his work should have indicated. He got his revenge with a comic strip for the post-punk fanzine City Fun that satirized the New Pop ideologues' superficial use of post-structuralist and postmodernist theories to justify their positions. It depicts a music journalist with an inspired expression exclaiming 'It is! Or it isn't! That is, I think. Perhaps maybe... I must write that one down'. The journalist is described as a 'post-monetarist', showing an astute awareness of New Pop's susceptibility to Thatcherite values (Lowry 1981). 